\title{
Economic Feasibility of Functional Meat Products for Commercial Production in India
}

\section{Varalakshmi Kandanuri* A R T I L E I N F O \\ Research Article \\ Received 13 October 2015 \\ Accepted 13 June 2017}

National Research Centre on Meat, Hyderabad-500092, India

Keywords:

Functional

Meat products

Investment analysis

Meat processing

Economies of scale

* Corresponding Author:

E-mail:kvslbk@yahoo.co.in

\section{A B S TR ACT}

This paper analyses the production of functional chicken meat products from economic perspectives. It analyses and compares the economics and investment feasibility on different size groups of processing plants in India. The primary data on input use and output yield were taken from studies of NRCM and data was analysed using economic analysis and investment appraisal techniques like NPV, IRR(\%), BC ratio, and Break even analysis. The results indicated that the cost of production of functional products was 5.2 and 5.18 and 4.59 US dollars per $\mathrm{kg}$ on small, medium and large scale units respectively. All the processing units are found to be economically feasible with NPV of US\$ 12727,64661 and 153703 , IRR of $26 \%, 31 \%$ and $42 \%$ and B-C ratio was estimated as 1.56, 1.78 and 2.29 for small, medium and large scale units respectively. Economies of scale is evident form all perspectives like production costs, profits, discounting measures and breakeven point. The study found the feasibility of functional meat products in India for commercial production.

DOI: https://doi.org/10.24925/turjaf.v5i7.701-709.554

\section{Introduction}

Rapid urbanization, consumer's awareness on safety, healthy and nutritious foods is increasing the demand for processed and high value foods supplemented with nutrients. This gives opportunities for functional foods.

Functional foods are a type of specialty products with health and nutritional benefits. Functional food products and natural health products encompass a wide range of food ingredients with a variety of bioactive compounds responsible for their efficacy in health promotion and disease prevention (NRCM, 2013).

There are mainly two types of functional foods, modified and fortified (Buisson, 1999). Functional foods are similar in appearance to conventional foods. These are consumed as part of a usual diet and are known to improve health status beyond basic nutritional function expected from the conventional foods (Shahidi, 2004).

They also provide biologically active components that impart health benefits. Such foods must possess characteristics like modified composition, limit the presence of certain potentially harmful components and incorporate certain desirable ingredients (JimenezColmenero, 1998; Jimenez-Colmenero et al., 2001).

Health benefits of functional materials can also be exploited in the meat sector. Meat and meat products are important sources of proteins, vitamins, and minerals, but they also impart animal fat, saturated fatty acids, cholesterol, common salt, etc. to the diet. Functional modification in meat and meat products includes modification of the fatty acid and cholesterol levels in meat, addition of vegetable oils, soy products and natural extracts with antioxidant properties, limiting sodium chloride, incorporation of dietary fibres and reduction of nitrite. These are the certain approaches to make meat and meat products as a functional food (Fernandez-Gene et al., 2005).

Functional foods are gaining importance in today's consumer world. Economic value of meat as rich source of proteins and minerals can further be improved by enriching with more functional ingredients. In a country like India where poultry meat enjoys advantage over other meats both in terms of production and consumption processed poultry meat products also exhibit comparative advantage over other products. This advantage can be further be exploited by production of functional and healthier processed chicken meat products. This comparative advantage of poultry meat products combined with healthier and nutritional benefits of functional ingredients will hold great opportunity for functional chicken meat products in India.

Though there were studies worldwide (Ball,1982; Deogade, 2008) in evaluation of Meat product technologies for economic worthiness and applicability, these technologies especially Functional meat products have not been evaluated for their economics in India. 
Functional meat products are found to be sound on technical aspects but their worthiness form economic perspectives is not yet established. Hence there is need to study the functional meat products from point of view of economics for the benefit of both producers and consumers.

Against this backdrop present study is taken up to study the economics of production of functional chicken meat products and evaluate the feasibility of setting up of meat processing plants on small, medium and large scale for the production of functional chicken meat products.

\section{Materials and Methods}

Primary data is collected from the experiments of the institute i.e. National Research Centre on Meat. The data corresponds to the cost of making product and cost of processing, time of processing, cost of Machinery and equipment etc. The primary data was collected for the year 2013-2014 and hence the input prices correspond to that year. Secondary data was used for outlining baseline assumptions.

\section{Technical Overview of Functional Meat Products}

Incorporation of a number of natural ingredients contribute to product quality by minimizing oxidative spoilage as well as providing health benefits. Honey, pomegranate juice and rind powder, ragi flour, ginger, kachri powder, grape and mosambi pulp, curry leaves, drumstick leaves, wheat and oat bran are some of the natural ingredients that could beneficially be incorporated in the production of value added convenience meat products (NRCM, 2013).

In NRCM many value added convenience functional meat products have been developed with different natural ingredients. Functional products are developed with mutton and chicken.

For the present study functional chicken meat products are considered. The product is prepared by incorporation of Lean meat (70\%), Maida (4\%), Spice mixture $(1.5 \%)$, condiments $(1.5 \%)$, Ice flakes $(10 \%)$, Poly phospahtes $(0.5 \%)$, Salt $(1.5 \%)$, Sugar $(0.5 \%)$, Sodium nitrite (100ppm) (0.01), Sunflower oil (10\%).

\section{Basic Assumptions}

The study uses basic assumptions for evaluating feasibility of functional meat product processing. These assumptions are related to construction and finance, production, working capital and depreciation. All the results are based on these assumptions.

These basic assumptions are same across all types of processing units except capacity in production assumptions and raw material holding period in working capital assumptions. Regarding working capital assumptions raw material holding period of 4 days is taken for small units while 12 days period is assumed for medium and large units. Production capacity is taken as $30 \mathrm{~kg}$ for small units, $150 \mathrm{~kg}$ for medium units and $400 \mathrm{~kg}$ for large units respectively.
Regarding production, it is assumed that the facility will process $30 \mathrm{~kg} / 150 \mathrm{~kg} / 400 \mathrm{~kg} /$ day and operate an eight hour shift, six days a week, 50 weeks a year with a capacity utilization rate of $60 \%, 70 \%$, in the first two years and $80 \%$ from third year onwards. Regarding Finance ratio of $3: 1$ is taken as banks and equity contribution. For calculation of IRR and net present value (NPV) of the project, cost of capital/interest rate of $12 \%$ set by commercial banks for long term loans has been taken Whereas, cost of working capital is taken as at $15 \%$ as per the rates fixed by the banks. Depreciation rates for WDV method as given by Companies Act 1956 are considered for calculation of depreciation schedule (kharabandaassociates.com). Depreciation rates of $10 \%$, $20 \%$ and $10 \%$ are considered for Buildings, Machinery and Miscellaneous assets respectively. As cost of land is not financed by banks, it is assumed that the entrepreneurs builts processing unit on his own land.

\section{Analytical Methods}

Various economic measures were used for evaluating the economics of functional chicken meat products. Financial efficiency measures like liquidity ratios, profitability ratios and investment ratios were employed for analysing financial viability of processing plant. Financial feasibility of investment was examined by using the regular project evaluation techniques like Net Present Value (NPV), Internal Rate of Returns (IRR), Benefit Cost Ratio(B-C ratio), Payback Period (Gittinger, 1982).etc. Break even analysis was also carried out.

\section{Economic feasibility measures}

Net present value $(N P V)$ : NPV is a popular measure of profitability used in corporate budgeting to assess a given project's potential return on investment. The NPV of a project or investment reflects the degree to which cash inflow, or revenue, equals or exceeds the amount of investment capital required to fund it. Net Present Value (NPV) is the difference between the present value of cash inflows and the present value of cash outflows.

The following is the formula for calculating NPV:

$$
N P V=\sum_{t=1}^{T} \frac{C_{t}}{(1+r)^{t}}-C_{0}
$$

Where;

$\mathrm{C}_{\mathrm{t}} \quad$ = net cash inflow during the period $\mathrm{t}$

$\mathrm{C}_{\mathrm{o}}=$ total initial investment costs

$\mathrm{r} \quad=$ discount rate and

$\mathrm{t} \quad=$ number of time periods

A positive net present value indicates that the projected earnings generated by a project or investment (in present dollars) exceeds the anticipated costs (also in present dollars). Generally, an investment with a positive NPV will be a profitable one and one with a negative NPV will result in a net loss. This concept is the basis for the Net Present Value (NPV) which dictates that the only investments that should be made are those with positive NPV values. 
Internal rate of return: Internal rate of return is a discount rate that makes the net present value of all cash flows from a particular project equal to zero. IRR calculations rely on the same formula as NPV does. IRR cannot be calculated analytically, and must instead be calculated either through trial-and-error or using software programmed to calculate IRR. The higher a project's internal rate of return, the more desirable it is to undertake the project.

Benefit cost ratio - BCR: A ratio attempting to identify the relationship between the cost and benefits of a proposed project. Benefit cost ratios are most often used in investment analysis to detail the relationship between possible benefits and costs, both quantitative and qualitative, of undertaking new projects or replacing old ones. It is given as the ratio of the sum of dis-counted benefit to the sum of discounted cost.

$$
\mathrm{BCR}=\Sigma\left(\mathrm{B}_{\mathrm{i}} /(1+\mathrm{r})^{\mathrm{i}}\right) / \Sigma\left(\mathrm{C}_{\mathrm{i}} /(1+\mathrm{r})^{\mathrm{i}}\right)
$$

Summed over $i=0$ to $n, n+1=$ the number of years over which benefits and costs are analysed, $B_{i}=$ the benefits of the project in year $i, i=0$ to $n, C_{i}=$ the costs of the project in year $i, r=$ the discount rate

According to Gittinger, 1989, the decision rule is that for an investment to be economically viable, the ratio must be greater than unity. The higher the ratio, the greater the benefits relative to the costs.

Payback period: The length of time required to recover the cost of an investment. The payback period of a given investment or project is an important determinant of whether to undertake the position or project, as longer payback periods are typically not desirable for investment positions.

$$
\text { Payback Period }=\frac{\text { Cost of Project }}{\text { Annual Cash Inflows }}
$$

\section{Break even analysis}

An analysis to determine the point at which revenue received equals the costs associated with receiving the revenue. Break even point is the point of zero profits.

$$
\text { Break Even Point }=\frac{\text { Fixed cost }}{\text { Contribution margin }}
$$

$$
\text { Contribution margin }=R P U-V C U
$$

RPU $=$ Revenue per unit,

$\mathrm{VCU}=$ Variable cost per unit

\section{Financial ratios analysis}

Financial ratios illustrate relationships between different aspects of a company's operations and provide relative measures of the firm's conditions and performance. Financial ratios are also used by investors to assess various attributes of a company's financial strength or operating results. A business's ability to obtain financing or equity financing will depend on the company's financial ratios. Financial ratios are categorized into Liquidity ratios, Profitability ratios, Investment ratios etc. according to the financial aspect of the business which the ratio measures.

Profitability ratios measure the company's use of its assets and control of its expenses to generate an acceptable rate of return. Following are the different profitability ratios employed in ratio analysis.

Gross profit margin is a key financial indicator used to asses the profitability of a company's core activity, excluding fixed cost.

Operating margin or operating profit margin measures what proportion of a company's revenue is left over, after deducting direct costs and overhead and before taxes and other indirect costs such as interest.

Net profit margin is a key financial indicator used to asses the profitability of a company. Net profit margin measures how much of each dollar earned by the company is translated into profits. A low profit margin indicates a low margin of safety: higher risk that a decline in sales will erase profits and result in a net loss.

Investment ratios examine how much profit the company generates with the money invested. These ratios include

Return on Equity (ROE) is an indicator of company's profitability by measuring how much profit the company generates with the money invested by common stock owners.

$$
\text { Return on Equity }=\left(\frac{\text { Net income }}{\text { Share holder's equity }}\right) \times 100
$$

Return on Investment (ROI) is an indicator of how profitable company's investment is in generating profit.

$$
\text { Return on Investment }=\left(\frac{\text { Net income }}{\text { Investment }}\right) \times 100
$$

Liquidity ratios examine the availability of company's cash to pay debt.

Debt Service Coverage Ratio (DSCR) measures enterprise's capacity to meet term-loan-cum-interest and other long-term commitments/ obligations.

$$
D S C R=\frac{(\text { Cash accrual }+ \text { Interest on term loan })}{\text { Interest on term loan }+ \text { Term loan repayment }}
$$

Debt Equity Ratio indicates the extent to which the promoter's funds are leveraged to procure loans.

$$
\text { Debt Equity Ratio }=\frac{\text { Total long term debt }}{\text { Total promoter's fund }}
$$

It would be desirable to maintain the DER between 2:1 and 3:1 for small and micro enterprises.

Operating ratio shows the efficiency of a company's management by comparing operating expense to net sales.

$$
\text { Operating ratio }=\frac{\text { Operating expense }}{\text { Net sales }}
$$


The smaller the ratio, the greater the organization's ability to generate profit if revenues decrease.

Debt-to-capital ratio is a solvency ratio that measures the proportion of interest-bearing debt to the sum of interest bearing debt and equity.

$$
\text { Debt }- \text { to }- \text { Capital Ratio }=\frac{\text { Total debt }}{\text { Capital }}
$$

\section{Results and Discussion}

\section{Capacity of Processing Plant}

Installed capacity: Capacity of the plant is assumed as 30,150 and $400 \mathrm{~kg} /$ day of Functional products for small, medium and large units respectively. Product yield of $100 \%$ is taken for Functional products as there is no cooking loss. Considering 300 working days in a year and yield of the products, the unit has an installed capacity of 9000, 45000 and $120000 \mathrm{~kg}$ Functional products. Product yield and Production at full capacity will be as shown in Table 1.

Capacity utilization: The capacity utilization varies depending on the capital availability, staff efficiency and availability of raw material. The plant is assumed to start production at $60 \%$ of its installed capacity in the first year and increase its production by $10 \%$ every year i.e $70 \%$, $80 \%$ in the second, third years and levelling off to $80 \%$ from $3^{\text {rd }}$ year onwards respectively. Output at utilized capacities for different units were given in Table 2

\section{Project Set Up Costs}

Project cost comprises investment for establishing an enterprise. The significant elements of project cost are land and site development, building, machinery, other fixed assets, technical know-how expenses, preliminary and pre- operative expenses, including interest during construction period, working capital margin and contingency costs. Investment pattern on different size groups of units is presented in Table 3

The total project outlay has been estimated at US\$ 22827, 82612 and 119405 for small, medium and large units respectively. The main infrastructural facilities required and detailed breakdown of project set up costs has been given below in Table 4 and the individual components are discussed in this section.

Land and land development: Processing unit requires a total area of 700, 1500 and 2500 sq. ft. of which 475 , 1160 and 1770 sq.ft will be covered by factory and office buildings, stores, etc. on small, medium and large units respectively. The land development cost varies considerably from place to place. Land development cost of US\$ 2.48 per sq.ft has been considered for this unit. The total cost of land development @ 2.48 per sq.ft will be US\$ 1735, 3719 and 6198.

Building and civil structures: The processing hall and other utilities would require construction of around 475, 1160 and 1770 sq.ft. of building at a total cost of US\$ 6264,15338 and 23405. The construction cost is assumed as US\$13.2 per sq.ft.
Preliminary \& preoperative expenses: This works out to US\$ 793, 7223 and 9537 which includes interest during construction, firm trial and registration.

Plant\& machinery: Plant \& Machinery including equipment works out to US\$ 10099, 39454 and 51685 and the cost of Misc. Assets works out to US\$ 1009, 3945 and 5168.

Contingencies: Contingency is a provision made for escalation of cost of equipment, between plan preparation and project implementation. An amount of US 1900 dollars is estimated towards escalation and contingencies for the first year to allow for price changes.

Investment pattern of processing units showed that machinery and equipment was the major item of cost contributing to $45.03 \%$ share followed by Buildings $(20.02 \%)$.These two items are the major costs for all three categories of plants with the share ranging from 43.29 to $47.76 \%$ for equipment's and 18.57 to $27.44 \%$ buildings respectively. these two items are followed by escalation and contingencies in case of small units while it is preliminary expenses for medium units and working capital for large units. However, in overall category working capital stands third position after equipment and buildings with share of $9.98 \%$. This can be attributed to high cost of working capital for large units. Overall investment structure shows that meat processing is a capital intensive venture.

\section{Means of Finance}

The project will be funded through both equity and debt in a $25 \%$ to $75 \%$ ratio. The debt will be repaid in a time period of 7 years including 1 year grace period. The project is proposed to be financed with a debt equity ratio of 3:1 and the means of finance is as follows

Credit linked subsidy of US 5256, 19702 and 22760 dollars for small, medium and large units is also availed through the subsidy scheme of Ministry of Food Processing Industry, GoI called Scheme of Technology Upgradation / Establishment/ Modernisation of Food Processing Industries under National Mission on Food Processing(as.ori.nic.in).

\section{Working Capital}

Working capital is the resources used to support a business until it is able to generate resources to support itself. Working capital varies with production level since it is directly related to variable operating expenses. Banks provide loans up to $70 \%$ of working capital requirement with an interest of $15 \%$. The remaining $30 \%$ will be born by the owner in the form of equity. Working capital requirement and its source of fiancé for different plants is presented in Table 4.

For small units working capital of US 2512 dollars is required out of which promoter has to contribute US 1008 dollars towards margin money. Increasing trend of working capital (Table 4) showed that production of functional meat products is capital intensive business requiring average working capital of US 19388 dollars. 
Table 1 Capacity of processing plant

\begin{tabular}{l|lcccc}
\hline S.No & Type of unit & Product yield & Days & Per day Capacity & Annual output (100\% capacity) \\
\hline 1 & Small & $100 \%$ & 300 & 30 & 9000 \\
2 & Medium & $100 \%$ & 300 & 150 & 45000 \\
3 & Large & $100 \%$ & 300 & 400 & 120000 \\
\hline
\end{tabular}

Table 2 Annual Capacity /capacity utilization for processing plant

\begin{tabular}{l|ccccccccc}
\hline \multirow{2}{*}{ Type of unit } & Installed & \multicolumn{7}{c}{ Output at utilized Capacity(kg) } \\
\cline { 2 - 10 } & Capacity & $1(60 \%)$ & $2(70 \%)$ & $3(80 \%)$ & $4(80 \%)$ & $5(80 \%)$ & $6(80 \%)$ & $7(80 \%)$ & $8(80 \%)$ \\
\hline Small & 9000 & 5400 & 6300 & 7200 & 7200 & 7200 & 7200 & 7200 & 7200 \\
Medium & 45000 & 27000 & 31500 & 36000 & 36000 & 36000 & 36000 & 36000 & 36000 \\
Large & 120000 & 72000 & 84000 & 96000 & 96000 & 96000 & 96000 & 96000 & 96000 \\
\hline
\end{tabular}

Table 3 Project Cost on different size groups of processing units (US \$)

\begin{tabular}{l|lcccccccc}
\hline \multirow{2}{*}{ S.No } & \multicolumn{2}{|c}{ Description } & \multicolumn{7}{c}{ Type of processing unit } \\
\cline { 3 - 9 } & & Small & $\%$ & Medium & $\%$ & Large & $\%$ & Overall & $\%$ \\
\hline 1 & Land and Fencing & 1735 & 7.60 & 3719 & 4.50 & 6198 & 5.19 & 3884 & 5.18 \\
2 & Building & 6264 & 27.44 & 15338 & 18.5 & 23405 & 19.60 & 15008 & 20.02 \\
3 & Machinery and Equipment & 10099 & 44.24 & 39454 & 47.7 & 51685 & 43.29 & 33752 & 45.03 \\
4 & Miscellaneous Assets & 1008 & 4.42 & 3950 & 4.78 & 5173 & 4.33 & 3372 & 4.51 \\
5 & Escalation \&Contingencies & 1900 & 8.33 & 6248 & 7.56 & 8644 & 7.24 & 5603 & 7.47 \\
6 & Preliminary\&Pre operative Expenses & 793 & 3.48 & 7223 & 8.74 & 9537 & 7.99 & 5851 & 7.81 \\
7 & WorkingCapitalMargin & 1008 & 4.42 & 6661 & 8.06 & 14777 & 12.38 & 7488 & 9.98 \\
\hline & Total cost(US \$) & 22827 & 100.00 & 82611.57 & 100 & 119405 & 100 & 74943 & 100 \\
\hline
\end{tabular}

Table 4 Working Capital requirement on different sizes of processing units

\begin{tabular}{l|ccc}
\hline \multirow{2}{*}{ Source } & \multicolumn{3}{c}{ Working capital(US \$) } \\
\cline { 2 - 4 } & Small & Medium & Large \\
\hline Total & 2512 & 16661 & 38975 \\
Bank & 1504 & 10000 & 24215 \\
Equity & 992 & 6661 & 14777 \\
\hline
\end{tabular}

\section{Project Economics}

Production costs: The production estimates for products are based on their output yields. The output yield/ input output ratio is taken as $100 \%$ for Functional products. The information regarding annual expenditure and per $\mathrm{kg}$ expenditure in the first year in preparation of functional meat products has been depicted in Table 5 .

It is clear from expenditure statement given in Table 5 that in total costs, raw material cost accounts for major share of $59.87 \%, 59.65 \%$ and $67.35 \%$ for small, medium and large units with overall share of $62.02 \%$. Raw material cost per $\mathrm{kg}$ was estimated as US 3.09 dollars for all units. Labour costs forms the second largest item of cost in total costs next to raw material with overall share of $9.81 \%$ (US\$ $0.49 / \mathrm{kg}$ ). Share of labour costs ranges from $8.71 \%$ (US\$ $0.4 / \mathrm{kg}$ ) for large units to $11.08 \%$ (US\$ $0.59 / \mathrm{kg}$ ) for small units. Depreciation is the third largest item with overall share of $7.76 \%$. Depreciation values were estimated as US\$ $0.57,0.4$ and 0.2 per $\mathrm{kg}$ of product. It can be concluded that raw material is the major item of cost followed by labour costs and depreciation and packaging materials. Further it is evident that these costs showed decreasing along the capacity reflecting efficient utilization of resources on large units resulting in lower costs.
Cost and return structure: Cost structure of functional products showed that the total cost of production was US\$ $5.2,5.18$ and 4.59 per $\mathrm{kg}$ of product for small, medium and large units respectively.

From Table 6 it is evident that on average variable and fixed costs accounted for $79.68 \%$ and $20.32 \%$ of total cost of production. Fixed costs varied from US\$ 1.16 (small units) to 0.73 (large units) with average of US\$ 1.16 per $\mathrm{kg}$. For variable costs this range is 4.04 (small units) to 4.03(large units) per kg. Average cost of production of functional meat products was estimated US\$ 4.99 with variable costs of US\$ 3.98 and fixed costs of US\$ 1.01 per kg.

Further it is evident that all the costs including variable and fixed costs goes on decreasing with the capacity due to efficient utilization of resources resulting in low production costs on larger units.

Revenue: First year revenues and profit for three types of units is given in Table 7

Gross revenue: At the selling price of US 5.72, 5.7 and 5.05 dollars $/ \mathrm{kg}$, the small, medium and large units generates gross revenue of US 30678, 153884 and 363455 dollars in the first year and this revenue goes on increasing in the subsequent years as capacity increases.

Net income: After considering taxes (Income tax and VAT), the net profit / net income is estimated as US 2645, 
13289 and 31388 dollars in the first year. The overall production of functional meat products generates gross returns of US\$ 182677 and net returns of US\$ 15769 lakhs which comes to US\$ 3.29 and 0.28 per $\mathrm{kg}$.

Both annual gross and Net returns increased proportionately with the capacity increase during successive years and also increase with size of the plant reflecting economies of scale (Arrow, 1998). Lower estimates of per $\mathrm{kg}$ net returns for large scale units can be attributed to the lower price of the product resulting from lower cost of production. This price can be increased by increasing mark-up percent to increase the net returns per $\mathrm{kg}$ along with size of the unit to reflect increasing trend as that of total net returns.

\section{Financial Evaluation}

\section{Financial ratio analysis}

On the basis of the projected income statement and related projections different financial ratios are calculated and shown in Table 8.

Profitability ratios: According to the projected income statement, the project will start generating the profits in the first year of operation. Profitability ratios indicate that on average functional products generates Gross profit margin of $24.78 \%$ and Operating Profit margin of $15.74 \%$ and profit margin of $13.45 \%$ and Net profit margin of $12.21 \%$.Operating ratio was found to be $84.26 \%$.

Gross and Operating Profit margin of $24.78 \%$ and $15.74 \%$ indicates that the direct costs incurred in the production of functional products accounts for $75.22 \%$ and operating expenses including administrative expenses and direct costs account for $84.2 \%$ of the profits. Difference between these two (9.04\%) gives administrative and selling expenses. It can also be depicted as the earnings before interest and taxes is $15.74 \%$. Profit margin indicates the profits before taxes is $13.45 \%$ and difference between Operating Profit margin and Profit margin indicates the interest incurred by the project which accounts for $2.29 \%$ of profits. It indicates the cost of the capital which is very important in investment decisions. It is used to compare across regions or financing institutions which will affect policy decisions.
Net profit margin indicates the actual profit that is left with the company after all expenses met and it is $12.21 \%$ in this case. Difference between Profit margin and Net Profit margin indicates that the taxes incurred by the unit accounts for $1.24 \%$ of the profits/sales. It is used to compare the tax structure of the countries or states or regions and it has implications for policy making for the growth of sector. All the profitability ratios show an increasing trend over the years.

Liquidity ratios: Liquidity ratios like Debt Service Coverage Ratio (DSCR), Debt Equity Ratio, Debt to capital Turn over were found to be kept at an acceptable levels of $4.06,1.16,28.94 \%$ respectively. These ratios show that the processing plant is able to meet its obligations on long term liabilities. Further decreasing trend (Table 8) of all these ratios shows that the Debt obligations goes on decreasing over the years and also along with capacity.

Though the DSCR which measures enterprise's capacity to meet term-loan-cum-interest and other longterm commitments/ obligations decreases in the second year it showed increasing trend throughout the period and is kept at acceptable level of 4.06 indicating that the plant generates surplus, adequate to meet repayment obligations. Debt equity ratio which measures the extent to which the promoter's funds are leveraged to procure loans is kept at 1.16. Hence Risk is found to be at the accepted levels and goes on decreasing over time and along with capacity.

All the liquidity ratios showed that the debt obligations decrease over time and surpluses generated by plant will go on increasing over time and also along with capacity.

Investment ratios: Analysis of investment ratios shows that on an average meat plant is able to generate enough returns of $31.29 \%, 125.16 \%$ returns on total investment and equity respectively. Investment turnover ratio is kept at $3.64 \%$.

To sum up, the financial viability indicators revealed that the processing unit is financially viable. Overall, the processing plant under study showed satisfactory performance on account of liquidity, profitability, investment.

Table 5 Cost of production of functional meat products in different sizes of plants (US \$)

\begin{tabular}{l|cccccccc}
\hline \multirow{2}{*}{ Particulars } & \multicolumn{3}{c}{ Small } & \multicolumn{2}{c}{ Medium } & \multicolumn{2}{c}{ Large } & \multicolumn{2}{c}{ Overall } \\
\cline { 2 - 8 } & Annual & Per kg & Annual & Per kg & Annual & Per kg & Annual & Per kg \\
\hline Raw Material & 16694 & 3.09 & 83455 & 3.09 & 222545 & 3.09 & 107570 & 3.09 \\
Stores, Consumables, Pac. Mat. & 2149 & 0.40 & 10711 & 0.40 & 28562 & 0.40 & 13802 & 0.40 \\
Power & 893 & 0.17 & 2083 & 0.08 & 4017 & 0.06 & 2331 & 0.10 \\
Utilities & 231 & 0.04 & 876 & 0.03 & 2215 & 0.03 & 1108 & 0.04 \\
Wages and Salary & 3091 & 0.59 & 13322 & 0.49 & 28793 & 0.40 & 15074 & 0.49 \\
Repairs and maintenance & 231 & 0.04 & 876 & 0.03 & 2215 & 0.03 & 1107 & 0.04 \\
Rent, Taxes, Insurance & 397 & 0.07 & 1190 & 0.04 & 2876 & 0.04 & 1488 & 0.05 \\
Admin expenses & 0.00 & 0.00 & 7620 & 0.28 & 12860 & 0.18 & 6827 & 0.15 \\
Selling expenses & 0.00 & 0.00 & 4281 & 0.16 & 4281 & 0.06 & 2860 & 0.07 \\
Interest on term loan & 1059 & 0.20 & 3802 & 0.14 & 5521 & 0.08 & 3455 & 0.14 \\
Interest on WC & 116 & 0.02 & 744 & 0.03 & 1818 & 0.03 & 893 & 0.02 \\
Depreciation & 3008 & 0.57 & 10793 & 0.40 & 14512 & 0.20 & 9438 & 0.39 \\
P\&P Amortization & 16.5 & 0.00 & 149 & 0.01 & 198 & 0.00 & 116 & 0.00 \\
Total & 27884 & 5.20 & 139901 & 5.18 & 330413 & 4.59 & 166066 & 4.98 \\
\hline
\end{tabular}


Table 6 Cost and Return structure of functional meat products in different sizes of units $(\mathrm{US} \$ / \mathrm{Kg})$

\begin{tabular}{l|ccccc}
\hline \multicolumn{1}{c|}{ Item of cost } & Small units & Medium units & Large units & Overall & $\%$ \\
\hline Variable costs & 4.04 & 4.03 & 3.86 & 3.98 & 1.32 \\
Fixed costs & 1.16 & 1.15 & 0.73 & 1.01 & 0.34 \\
Total costs & 5.20 & 5.18 & 4.59 & 4.99 & 1.65 \\
Sellingprice@ 10\%markup & 5.72 & 5.70 & 5.05 & 5.49 & \\
\hline
\end{tabular}

Table 7 Returns from functional meat products in different size groups of units(US \$)

\begin{tabular}{|c|c|c|c|c|c|c|c|c|}
\hline \multirow{2}{*}{ Particulars } & \multicolumn{2}{|c|}{ Small } & \multicolumn{2}{|c|}{ Medium } & \multicolumn{2}{|c|}{ Large } & \multicolumn{2}{|c|}{ Overall } \\
\hline & Annual & Per kg & Annual & Per kg & Annual & Per kg & Annual & Per kg \\
\hline Income & 30678 & 3.41 & 153884 & 3.42 & 363455 & 3.03 & 182677 & 3.29 \\
\hline Expenditure & 27884 & 3.10 & 139901 & 3.11 & 330413 & 2.75 & 166066 & 2.99 \\
\hline Profit Before Tax & 2793 & 0.31 & 13984 & 0.31 & 33041 & 0.28 & 16612 & 0.30 \\
\hline Residual value & 0.00 & 0.00 & 0.00 & 0.00 & 0.00 & 0.00 & 0.00 & 0.00 \\
\hline Profit Before Tax & 2793 & 0.31 & 13984 & 0.31 & 33041 & 0.28 & 16612 & 0.30 \\
\hline Taxable profit & 0.00 & 0.00 & 0.00 & 0.00 & 0.00 & 0.00 & 0.00 & 0.00 \\
\hline Income tax & 0.00 & 0.00 & 0.00 & 0.00 & 0.00 & 0.00 & 0.00 & 0.00 \\
\hline vat $5 \%$ & 132 & 0.01 & 694 & 0.02 & 1653 & 0.01 & 826 & 0.01 \\
\hline Total taxes & 132 & 0.01 & 694 & 0.02 & 1653 & 0.01 & 826 & 0.01 \\
\hline Profit after Tax & 2645 & 0.29 & 13289 & 0.30 & 31388 & 0.26 & 15769 & 0.28 \\
\hline Non cash expenditure & 3025 & 0.34 & 10942 & 0.24 & 14711 & 0.12 & 9554 & 0.23 \\
\hline Cash profit & 5670 & 0.63 & 24231 & 0.54 & 46099 & 0.38 & 25323 & 0.52 \\
\hline
\end{tabular}

Table 8 Financial feasibility Ratios of Functional meat products

\begin{tabular}{|c|c|c|c|c|}
\hline \multirow{2}{*}{ Financial feasibility Ratios } & \multicolumn{4}{|c|}{ Capacity } \\
\hline & Small & Medium & Large & Overall \\
\hline \multicolumn{5}{|l|}{ Profitability Ratios } \\
\hline Gross profit margin(\%) & 24.84 & 28.23 & 21.27 & 24.78 \\
\hline Operating Profit margin $(\%)$ & 18.12 & 15.85 & 13.26 & 15.74 \\
\hline Profit margin $\%$ & 15.42 & 13.50 & 11.44 & 13.45 \\
\hline Net Profit margin $(\%)$ & 14.22 & 12.20 & 10.22 & 12.21 \\
\hline \multicolumn{5}{|l|}{ Investment Ratios } \\
\hline Return on Total investment & 24.80 & 29.28 & 39.79 & 31.29 \\
\hline Return on Equity & 99.21 & 117.12 & 159.14 & 125.16 \\
\hline Investment turnover ratio & 4.59 & 3.71 & 2.62 & 3.64 \\
\hline \multicolumn{5}{|l|}{ Liquidity ratios } \\
\hline Debt Equity Ratio & 1.17 & 1.15 & 1.15 & 1.16 \\
\hline Debt to Capital Turn over & 29.20 & 28.76 & 28.85 & 28.94 \\
\hline Debt Service Coverage Ratio & 3.37 & 3.90 & 4.91 & 4.06 \\
\hline Operating ratio & 81.88 & 84.15 & 86.74 & 84.26 \\
\hline
\end{tabular}

\section{Economic Feasibility}

In the present study, economic feasibility of processing unit was measured using discounted measures such as NPV, BCR, IRR and Pay Back period.

The calculated IRR of the project is $26 \%, 31 \%$, and $42 \%$ and Net Present Value (NPV) at $12 \%$ discount is US\$ 12727, 64661 and 153703 for small, medium and large units respectively. The positive NPV (Table 9) implied that the discounted worth of benefits was greater than disconnected worth of cost steams. The project's initial investment will be fully recovered in less than three years $(3,2.72 \& 2.13$ years) with average annual net returns of US\$ 7355, 30331 and 55835 per annum. Benefit cost ratio being greater than unity $(1.56,1.78$ and 2.29) reaffirmed that processing plants are viable and on average the plants will give a return of 1.56,1.78 and 2.29 on every dollar investment on small, medium and large units respectively.
According to the discounting criteria the processing plants under study turned out to be economically viable projects with NPV of US\$ 77025 and IRR of 33\%, BC ratio of 1.88 and payback period of 2.62 years. The plant generates average returns of US\$ 31174 per year.

\section{Break Even Analysis}

Break Even Analysis indicates that BEP of output is $3736 \mathrm{kgs}, 18619 \mathrm{kgs}$ and $44211 \mathrm{kgs}$ which comes at $69.2 \%$, $68.96 \%$ and $61.4 \%$ of utilized capacity and $41.52 \%$, $41.38 \%$ and $36.84 \%$ of full capacity of small, medium and large units respectively.

In order to reach BEP one has to produce $3736 \mathrm{kgs}$, $18619 \mathrm{kgs}$ and $44211 \mathrm{kgs}$ of functional products where the expenditure and income will be equal and profit will be zero. The remaining output $(30.8 \%, 31.04 \% 38.6 \%)$ is considered as margin of safety where profits start generating. 
Attainment of BEP at lesser time (Table 10) at higher levels of capacity utilization indicates that the plant is financially feasible. It is evident from Table 10 that margin of safety shows positive relation with capacity showing higher profits on large units. The results are in conformity with the economic theory.

Table 9 Economic Feasibility measures for meat processing plant

\begin{tabular}{l|lcccc}
\hline S.No & \multicolumn{1}{c}{ Feasibility measures } & Small & Medium & Large & Overall \\
\hline 1 & NPV(US \$) & 12727 & 64661 & 153703 & 77025 \\
2 & IRR(\%) & $26 \%$ & $31 \%$ & $42 \%$ & $33 \%$ \\
3 & BC & 1.56 & 1.78 & 2.29 & 1.88 \\
4 & Average Returns (Un Discounted) (US \$) & 7355 & 30331 & 55835 & 31174 \\
5 & Pay Back Period (Yrs) & 3 & 2.72 & 2.13 & 2.62 \\
6 & Average Returns(Discounted) (US \$) & 1587 & 8083 & 19207 & 9620 \\
7 & DSCR & 3.37 & 3.89 & 4.91 & 4.06 \\
\hline
\end{tabular}

Table 10 Break even analysis

\begin{tabular}{|c|c|c|c|}
\hline Particulars & Small & Medium & Large \\
\hline Total output(kg)/yr & 5400 & 27000 & 72000 \\
\hline Break Even Point(Capacity) & 3736.63 & 18619.41 & 44211.24 \\
\hline Break Even Point (as \% of Capacity) & 69.20 & 68.96 & 61.40 \\
\hline Break Even Point (as \% of Full Capacity) & 41.52 & 41.38 & 36.84 \\
\hline Total Revenue(US \$) & 21223 & 106132 & 223174 \\
\hline Total Variable cost(US \$) & 14959 & 75041 & 170612 \\
\hline Total Fixed Cost(US \$) & 6265 & 31074 & 52562 \\
\hline Total Cost(US \$) & 21223 & 106132 & 223174 \\
\hline Profit & 0 & 0 & 0 \\
\hline
\end{tabular}

\section{Conclusions}

In the present study economics of functional meat products was investigated. Ex ante analysis of meat processing unit for functional meat products was carried out. Three types of processing units were compared for profitability, viability. Production data was taken from studies of NRCM and analysed using economic criteria like NPV, IRR, BC ratio, Breakeven analysis.

The results revealed that for functional meat products, the highest share $(62.02 \%)$ in total cost was constituted by meat which is main raw material, and it was followed by labour costs $(9.81 \%)$ and depreciation $(7.76 \%)$. So, there is a need to take corrective policy, management measures to keep the raw material prices as low as possible. The results revealed that the cost of production was higher (US\$ 5.2/kg) in the case of small units followed by medium (US\$ $5.18 / \mathrm{kg}$ ) and large units(US\$ $4.59 / \mathrm{kg}$ ) resulting in higher profits on large units which reflected the economies of scale.

Based on ratio analysis performed, average gross profit margin, operating profit margin, profit margin and net profit were found to be $24.78 \%, 15.74 \%, 13.45 \%$ and $12.21 \%$ respectively.

Gross and Operating Profit margin of $24.78 \%$ and $15.74 \%$ indicates that the direct costs incurred in the production of functional products accounts for $75.22 \%$ and operating expenses including administrative expenses and direct costs account for $84.2 \%$ of the profits. Interest and taxes incurred by the project which accounts for $2.29 \%, 1.24 \%$ of profits. All the profitability ratios show an increasing trend over the years. Risk measured in terms of Liquidity ratios is found to be at the accepted levels and goes on decreasing over time resulting in increased surplus during successive years.

To sum up, ratio analysis revealed that all the processing units is profitable and financially viable. Overall, the processing plants under study showed satisfactory performance on account of liquidity, profitability, investment.

According to the discounting criteria the processing plants under study turned out to be economically viable projects with NPV of US 77025 dollars and IRR of 33\%, $\mathrm{BC}$ ratio of 1.88 and payback period of 2.62 years. The plant generates average returns of US\$ 31174 per year.

The results of the feasibility analysis showed that the NPV, IRR, BC and Payback periods were quite acceptable for all the categories of the units which clearly indicate the financial worthiness of functional meat production.

Under base scenario, according to the NPV criteria the processing plants under study turned out to be economically viable projects. The positive NPV implied that the discounted worth of benefits was greater than disconnected worth of cost steams. Benefit cost ratio being greater than unity $(1.56,1.78,2.29)$ reaffirmed that processing plant is viable and on average the plant will give a return of $1.56,1.78,2.29$ with average of Rs.1.88 on every dollar investment.

Break Even Analysis showed that margin of safety increases in successive years and it shows positive relation with capacity resulting in higher profits on large units.

To conclude functional chicken meat products are profitable irrespective of the size of the processing units. 
But capital intensive nature of the business poses limitations for commercialization of these technologies. This calls for evolving policy measures by the planners to promote the processing units on large scale. Govt should take the measures to provide financial support to the entrepreneurs in the form of capital subsidies, interest subsidies, incentives like exemption from taxes etc. Govt should also ensure that the Financial institutions provide the loans with hassle free mechanism at lower interest rates to the entrepreneurs. Govt and research institutes should ensure that technology generated in the labs should reach the ultimate target groups. for this Govt should also take initiatives to impart the training on technical knowhow of the products through its newly launched scheme "skill development programme" so that more business players especially small and medium scale entrepreneurs will make their way into the meat processing business. Moreover, it will provide impetus to the food processing industry besides making healthy and nutrient enriched meat products available to the consumers.

\section{Acknowledgement}

The authors are grateful to ICAR for extending support to take up this research project.

\section{References}

Arrow KJ. 1998. Innovations and Increasing Returns to Scale. In: K. J. Arrow, Y-K Ng, and X. Yang (Eds). Increasing Returns and Economic Analysis. New York: St. Martin's Press

Ball VE, Chambers RG. 1982. An Economic Analysis of Technology in the Meat Products Industry. American Journal of Agricultural Economics; 64: 699-709.

Deogade AH, Zanjad PN, Raziuddin M. 2008. Value Added Meat Products. Vet.World; 1:88-89.

Fernandez JM, Fernandez J, Sayas E, Perez JA. 2005. Meat products as functional foods: a review. J Food Sci; 2005; 70:R37-R43. doi: 10.1111/j.1365-2621.2005.tb07110.x.

Gittinger JP. 1989. Economic Analysis of Agricultural pro-jects. London: The John Hopkins University press.

Jimenez CF. 1996. Technologies for developing low fat meat products. Trends Food Sci. Technol; 7: 41-48.

Jimenez-Colmenero F, Carballo J, Cofrades S. 2001. Healthier meat and meat products: their role as functional foods. Meat Sci; 2001:59:5-13. doi: 10.1016/S0309-1740(01)00053-5.

Sen AR. 2013. Technology for speciality meat products with health and nutritional benefits.In : NRCM (Eds). Towards organized meat sector development : Technologies and Success stories. pp.7.

Shahidi F, Samaranayaka AGP. 2004. Brine. In: W.K. Jensen, C. Devine, M. Dikeman(Eds). Encyclopedia of meat sciences. U.K: Elsevier, Oxford. pp. 366-374.

http://www.kharabandaassociates.com/Downloads/Dep\%20Rates\% 20-\%20Co.\%20Act.pdf. Accessed 6 October 2015

http://as.ori.nic.in/diorissa/guidelines_28.08.12.pdf. Accessed 6 October 2015 